\title{
Development of the L-type CaV / BK Complex Simulator (I): electrophysiological interaction
}

DOI: $10.46932 / \mathrm{sfjdv2n2-009}$

Received in: November 1st, 2020

Accepted in: December 30th, 2020

\author{
Marleni Reyes Monreal \\ $\mathrm{PhD}$ student in History \\ (Instituto de Ciencias Sociales y Humanidades BUAP) \\ PI. School of Visual and Audiovisual Arts (ARPA), BUAP. \\ Complejo Cultural Universitario (CCU). Puebla, Pue. México. \\ E-mail: marleni.reyes@correo.buap.mx
}

\section{Jessica Quintero Pérez}

PhD student in Biomechanics and Bioengineering Applied to Health (Universidad de Alcalá, España).

PHC. Degree in Physiotherapy-Faculty of Medicine.

Benemérita Universidad Autónoma de Puebla (BUAP).

Health area. Puebla, Pue. México.

E-mail: jessica.quintero@correo.buap.mx

Miguel Felipe Pérez Escalera

PhD student in Computer Sciences

(Universidad de las Américas UDLAP)

PI. School of Visual and Audiovisual Arts (ARPA), BUAP.

Complejo Cultural Universitario (CCU). Puebla, Pue. México.

E-mail: miguel.escalera@correo.buap.mx

Arturo Reyes Lazalde

$\mathrm{PhD}$ in Basic Biomedical Research (UNAM)

PI. Holder of the Faculty of Biological Sciences, BUAP.

Ciudad Universitaria. Puebla, Pue. México.

E-mail: arturoreyeslazalde@yahoo.com.mx

María Eugenia Pérez Bonilla

PhD in Experimental Pathology (CINVESTAV-IPN, Mx) PI. Holder of the Faculty of Biological Sciences, BUAP.

Ciudad Universitaria. Puebla, Pue. México.

E-mail: maria.perez@ correo.buap.mx

\begin{abstract}
Complexes formed by voltage-activated calcium channels $(\mathrm{CaV})$ and high-conductance potassium channels activated by $\mathrm{Ca}^{2+}$ (BK) have been studied in smooth muscle, secretory cells and in synaptic terminals, where they regulate muscle contraction, secretory activity, and neurotransmission. However, the complex formed by L- type $\mathrm{CaV}$ channels and BK in the soma has been poorly treated. Based on immunostaining studies showing the coexistence of these channels in the neuron soma, their possible interaction was theoretically studied. Two simulators based on the Hodgkin and Huxley formalism were developed to perform virtual experiments on current and voltage clamp. The mathematical models were implemented in Visual Basic ${ }^{\circledR} 6.0$ and were solved numerically. The results indicate that the BK channels
\end{abstract}


were activated with internal $\mathrm{Ca}^{2+}$ at $\mu \mathrm{M}$ concentrations. The BK channels follow the kinetics of L-type $\mathrm{CaVs}$. The interaction of L-type $\mathrm{CaV}-\mathrm{BK}$ complex in the soma produced a decrease in neuronal excitability.

Keywords: Simulators, BK channels, L-type CaV channels, Neuronal excitability

\section{INTRODUCTION}

\subsection{BK CHANNELS}

Calcium and voltage-gated high-conductance K channels (BK channels) are ubiquitously expressed in a wide variety of neurons (Contet et al., 2016) and non-tissue neurons where they play an important role in the regulation of physiological processes such as the modulation of smooth muscle contraction, secretion, cardiac pacemaker frequency, neurotransmitter release, control of neuronal firing patterns and neuronal excitability, (Ha \& Cheong, 2017; Jackson, 2018; Kshatri et al., 2018). At a cellular level, they are located in synaptic terminals, dendrites, axon, and soma (Misonou et al., 2006). In the soma, the pyramidal neurons show two distinct types of localization, a scattered and a groups pattern (Kaufmann et al., 2009). The clinical relevance of dependence on these channels has been reported in several diseases such as benign familiar neonatal seizure, episodic ataxia, epilepsy, and chronic pain (Contet et al., 2016). The role of BK channels in epilepsy is controversial and is a growing area of intense research. These channels are associated with voltage-gated calcium channels $(\mathrm{CaV})$ distributed in somatodendritic gradients. They are associated with $\mathrm{P} / \mathrm{Q}$ type $\mathrm{CaV}$ in different somatic coclustering in Purkinje neurons (Indriati et al., 2013). The association in the soma of L-type CaV with BK channels has been little studied.

BK is encoded by a single gene (KCNMA1, SLO-1), it is made up of four alpha subunits and has 7 transmembrane subunits (Lee \& Cui, 2010). Two different classes of auxiliary subunits have been identified: $\beta$ subunit and $\gamma$ subunit. It has been intensively investigated and established that $\beta$ ( $\beta 1-\beta 4)$ subunits modulate the activity of the BK channel (Li \& Yan, 2016). These channels have a high conductance per single channel $\sim 250$ pS (100-300 pS) (at symmetric $\mathrm{K}^{+}$concentrations) (Butler et al., 1993). They open in response to the depolarization of the membrane, due to an increase in the internal calcium concentration $\left(\left[\mathrm{Ca}^{2+}\right]_{\mathrm{i}}\right.$ ) or because of both (Ramon Latorre et al., 2017). The BK channel has been reported to have two putative calcium-binding sites located in the RCK2 and RCK1 domains (Lee \& Cui, 2010). Subunits modulate BK channels (Contet et al., 2016). The activation voltage for the BK channel depends on $\left[\mathrm{Ca}^{2+}\right]_{\mathrm{i}}$ (Miranda et al., 2018). Brenner et al (2000) found that at a membrane potential $\sim 100$ $\mathrm{mV}$, BK channels become activated with $\left[\mathrm{Ca}^{2+}\right]_{\mathrm{i}}$ at concentrations $\geq 10 \mu \mathrm{M}$. The affinity of BK channels for $\mathrm{Ca}^{2+}$ ranges from 1 to $10 \mu \mathrm{M}$ (Contreras et al., 2013). These channels contribute to the repolarization of the action potential (AP) and mediate the rapid phase of post-hyperpolarization (fAHP) that follows the 
AP (Lancaster \& Nicoll, 1987). The $\mathrm{K}^{+}$output current tends to hyperpolarize the cell and attenuates the effect of the excitatory stimuli.

\subsection{L-TYPE VOLTAGE-GATED CALCIUM CHANNELS}

$\mathrm{Ca}^{2+}$ is an ion of utmost importance for cells. In general, it is a signaling system. It converts electrical signals into chemical signals and its response depends on the specific cell type: secretion, metabolism, cell proliferation, contraction, excitability, and gene expression. (Bean, 1989). [Ca $\left.{ }^{2+}\right]_{i}$ comes from two sources: influx by voltage-gated $\mathrm{Ca}^{2+}$ channels $(\mathrm{CaV})$ and by the efflux of the reticular system (endoplasmic or sarcoplasmic). In neurons, there are various types of voltage-gated $\mathrm{Ca}^{2+}$ channels. Due to their biophysical and pharmacological characteristics, they can be classified into 5 families: T-type, Ltype, N-type, P/Q-type, and R-type $\mathrm{Ca}^{2+}$ (Tsien et al., 1988). Specifically, the L-type channels have a $\sim 25$ $\mathrm{pS}$ conductance, do not significantly activate during the depolarization of hundreds of milliseconds, are sensitive to dihydropyridine, and have a very slow inactivation rate $(\tau>500 \mathrm{~ms}$ ) (Tsien et al., 1988). Ltype channels are located in a variety of neurons (Tsien et al., 1991) and are mainly located in the cell body and proximal dendrites (Hell et al., 1993). They have been studied mainly in secretory cells, cardiac muscle, and in neurons in the control of neurotransmission. In synaptic transmission, the distance between $\mathrm{CaV}$ and the receptor that initiates exocytosis can be $\sim 50 \mathrm{~nm}$ (Augustine et al., 2003). They regulate synaptic plasticity and blockers such as nifedipine (dihydropyridine) would modulate brain function (Striessnig et al., 2006).

Electrophysiologically, there is interaction between the L-type voltage-gated calcium channel and the BK channel in a variety of neurons forming nanodomains (Vivas et al., 2017). In the suprachiasmatic nucleus, a differential contribution of calcium sources between day and night for the activation of BK current in the circadian clock has been demonstrated. L-type calcium channels are the primary source of calcium during the day for the activation of BK channels (Whitt et al., 2018). The coexistence and the activation of BK channels by L-type calcium channels have been studied in different tissues (Bellono et al., 2017; Vivas et al., 2017). The precise functional interaction between the $\mathrm{CaV}$ and BK channels remains unclear (Müller et al., 2007). The role of L-type calcium channel complexes and BK channels in the neuron soma has been sparsely addressed. 


\subsection{OBJECTIVE}

The objective of this work are: (1) Develop simulators of the L-type CaV / BK complex, and (2) theoretically explore the interaction of the L-type $\mathrm{CaV} / \mathrm{BK}$ complex in neuron soma, using simulators that allow virtual experiments under current and voltage clamp conditions.

\section{MATERIAL AND METHODS}

Two simulators were designed and developed for the theoretical study of the L-type CaV/BK channel complex in the somatic membrane. (1) Simulator for experiments with current clamp technique, (2) Simulator for experiments with the voltage clamp technique. The electrical activity of the neuron was reproduced with Hodgkin and Huxley formalism (Hodgkin \& Huxley, 1952).

\subsection{SIMULATORS OF THE L-TYPE CAV/BK COMPLEX FOR EXPERIMENTS IN VOLTAGE AND CURRENT CLAMP.}

In the first simulator (voltage clamp) the somatic membrane has voltage dependent $\mathrm{Na}^{+}$and $\mathrm{K}^{+}$ channels to generate a train of action potentials, described as a control condition and L-type CaV channels and BK channels are added to generate the experimental conditions that modify the AP train. In the second simulator (current clamp) the somatic membrane has L-type $\mathrm{CaV}$ channels and BK channels. The equations that integrate the model are the following (Hodgkin \& Huxley, 1952; Sterratt et al., 2011) (Eqs. 1 to 10).

$$
\begin{aligned}
& -C_{m} \frac{d V}{d t}=g_{N a} m^{3} h\left(V-E_{N a}\right)+g_{K} n^{4}\left(V-E_{k}\right)+g_{L}\left(V-E_{L}\right)+g_{C a} m_{C a}^{2} h_{C a}\left(V-E_{C a}\right)+g_{B K} q(V- \\
& \left.\quad E_{B K}\right) \\
& \frac{d m}{d t}=\alpha_{m}(V)(1-m)-\beta_{m}(V) m \\
& \frac{d h}{d t}=\alpha_{h}(V)(1-h)-\beta_{h}(V) h \\
& \frac{d n}{d t}=\alpha_{n}(V)(1-n)-\beta_{n}(V) n
\end{aligned}
$$

Where:

$\mathrm{V}$ is the voltage of the membrane and $\mathrm{C}_{\mathrm{m}}$ is membrane capacitance. The conductances for sodium, potassium, leakage, L-type calcium and high-conductance calcium-dependent potassium are: $\mathrm{g}_{\mathrm{Na}}, \mathrm{g}_{\mathrm{K}}, \mathrm{g}_{\mathrm{L}}$, $\mathrm{g}_{\mathrm{Ca}}, \mathrm{g}_{\mathrm{BK}}$ and $\mathrm{E}_{\mathrm{Na}}, \mathrm{E}_{\mathrm{K}}, \mathrm{E}_{\mathrm{L}}, \mathrm{E}_{\mathrm{Ca}} \mathrm{E}_{\mathrm{BK}}$ are the corresponding to equilibrium potentials, $\mathrm{m}$ is the activation constant for $\mathrm{Na}^{+}, \mathrm{h}$ is the inactivation constant for $\mathrm{Na}^{+}, \mathrm{n}$ is the activation constant for $\mathrm{K}^{+}, \mathrm{m}_{\mathrm{Ca}}$ is the 
activation constant for L-type $\mathrm{Ca}^{2+}$, $\mathrm{h}_{\mathrm{Ca}}$ is the inactivation constant for $\mathrm{L}$-type $\mathrm{Ca}^{2+}, \mathrm{q}$ is the activation constant for BK. The parameters used are: $\mathrm{E}_{\mathrm{Na}}=115, \mathrm{E}_{\mathrm{K}}=-77, \mathrm{E}_{\mathrm{L}}=-54.4 \mathrm{E}_{\mathrm{Ca}}=140, \mathrm{E}_{\mathrm{BK}}=-140(\mathrm{mV})$, $\mathrm{g}_{\mathrm{Na}}=120, \mathrm{~g}_{\mathrm{K}}=36\left(\mathrm{mS} / \mathrm{cm}^{2}\right), \mathrm{g}_{\mathrm{Ca}}$, and $\mathrm{g}_{\mathrm{BK}}\left(\mu \mathrm{S} / \mathrm{cm}^{2}\right)$ are designated by the simulator user.

The empirical equations for $\mathrm{Na}^{+}$and $\mathrm{K}^{+}$currents: $\alpha_{\mathrm{m}}, \beta_{\mathrm{m}}, \alpha_{\mathrm{n}}, \beta_{\mathrm{n}}, \alpha_{\mathrm{h}}$, and $\beta_{\mathrm{h}}$ are as follows (Eqs. 5 to $10)$.

$$
\begin{aligned}
& \alpha_{m}=\frac{0.1(V+35)}{1-\exp \left(-\frac{V+50}{10}\right)} \\
& \beta_{m}=4 \exp \left(-\frac{V+60}{18}\right) \\
& \alpha_{h}=0.07 \exp \left(-\frac{V+60}{20}\right) \\
& \beta_{h}=1 /\left(1+\exp \left(-\frac{V+30}{10}\right)\right. \\
& \alpha_{n}=\frac{0.01(V+50)}{1-\exp \left(-\frac{V+50}{10}\right)} \\
& \beta_{n}=0.125 \exp \left(\frac{V+60}{30}\right)
\end{aligned}
$$

Where the velocity coefficients for $\mathrm{Na}^{+}$are $\alpha_{\mathrm{m}}, \beta_{\mathrm{m}}, \alpha_{\mathrm{h}}, \beta_{\mathrm{h}}$, and for $\mathrm{K}^{+}$are $\alpha_{\mathrm{n}}$ and $\beta_{\mathrm{n}}$.

Equations for the L-type $\mathrm{Ca}^{2+}$ current are the following ( Pospischil et al., 2008) (Eqs. 11 to 15).

$$
\begin{aligned}
& I_{C a}=\bar{g}_{C a} m_{C a}^{2} h_{C a}\left(V-E_{C a}\right) \\
& h_{C a}=\frac{K}{K+\left[C a^{2+}\right]_{i}}, \mathrm{~K}=7.2 \\
& \frac{d m_{C a}}{d t}=\propto_{m_{C a}}(V)\left(1-m_{C a}\right)-\beta_{m} m_{C a}
\end{aligned}
$$

The $\alpha_{\mathrm{mCa}}$ and $\beta_{\mathrm{mCa}}$ are expressed empirically (Eqs 14 and 15).

$$
\propto_{m_{C a}}=\frac{0.055(-27-V)}{\exp \left(\frac{-27-V}{3.8}-1\right)}
$$




$$
\beta_{m_{C a}}=0.94 \exp \left(\frac{-75-V}{17}\right)
$$

\subsection{EQUATION TO CALCULATE $\left[\mathrm{Ca}^{2+}\right]_{\mathrm{i}}$ FROM THE $\mathrm{Ca}^{2+}$ CURRENT}

Based on the work of Wang (1998), Eq. 16 was used to derive $\left[\mathrm{Ca}^{2+}\right]_{\mathrm{i}}$ from the $\mathrm{Ca}^{2+}$ current (Traub, 1982, 1991; Wang, 1998).

$\frac{d\left[\mathrm{Ca}^{2+}\right]_{i}}{d t}=\propto_{C a} I_{C a}-\frac{\left[\mathrm{Ca}^{2+}\right]_{i}}{\tau_{C a}}$

$\tau_{\mathrm{Ca}}$ is the time constant of the buffering process and $\alpha_{\mathrm{Ca}}$ is a constant. Helmchen et al. (1996) and Markram et al. (1995) propose a value for $\alpha$ of $0.002\left(\mu \mathrm{M}(\mathrm{ms} \mu \mathrm{A})^{-1} \mathrm{~cm}^{2}\right)$, with an influx of $\mathrm{Ca}^{2+}$ of $\sim 200$ $\mathrm{nM}$ per spike and a time constant $\tau_{\mathrm{Ca}}$ of $80 \mathrm{~ms}$.

\subsection{EQUATIONS FOR BK CURRENT}

The equations for the calculation of the BK current are (Eqs. 17 and 18):

$I_{B K}=\bar{g}_{B K} \mathrm{q}\left(V-E_{B K}\right)$

$\frac{d q}{d t}=\alpha_{q}(V)(1-q)-\beta_{q} q$

The $\alpha_{\mathrm{q}}$ and $\beta_{\mathrm{q}}$ are expressed empirically (Eqs. 19 and 20).

$\alpha_{q}=\frac{\exp \left(\frac{V}{27}\right) 0.005\left(200-\left[\mathrm{Ca}^{2+}\right]_{i}\right)}{\exp \left(\frac{200-\left[\mathrm{Ca}^{2+}\right]_{i}}{20}\right)-1}$

$\beta_{q}=0.0004$ to 0.0002

The type-L CaV/BK complex simulator for current and voltage clamp consider the pharmacological action of the BK channel blockers: iberiotoxin (Galvez et al., 1990) and charybdotoxin (Cui et al., 2009) and the L-type $\mathrm{Ca}^{2+}$ current blocker with nifedipinae (Striessnig et al., 2006), here reflected as a decrease in conductances for BK and L-type $\mathrm{CaV}$, respectively. 
The equations of the simulators were implemented in Visual Basic 6.0 for Windows ${ }^{\circledR} 7$ to 10 environment and interfaces, which allow interactive experiments to be carried out in multiple experimental conditions, were designed. To start the integration, a fourth-order Runge-Kutta method with a step time of $\mathrm{dt}=0.01$ was used. An algorithm written in basic to solve differential equations with this method is found in Zill (Zill, 1988).

The simulators generate ASCII files to be exported to graphing and analysis programs. All data analysis was performed with Origin 6.0 graphing and curve fitting software, and the Levenberg-Marquardt algorithm was used to perform nonlinear least-squares fits. BK and $\mathrm{CaV}$ conductance-voltage (G-V) relations were determined from the amplitude voltage steps to the test voltage. Each G-V relation was then fitted with a Boltzmann function (Cox, 2014) (Eq. 25).

$$
\frac{G}{G_{\max }}=\frac{1}{1+\exp \left[\left(V_{\frac{1}{2}}-V\right) \frac{z F}{R T}\right.}
$$

\section{RESULTS}

\subsection{SIMULATOR INTERFACE AND CONTROL SIMULATION.}

The simulator for the experiments with the current clamp technique is shown in Figure 1. It is divided into two sectors, one on the right side, for data entry: stimulus pulse, external and internal $\mathrm{Ca}^{2+}$ concentrations, conductances for the channels $\mathrm{BK}$ and L-type $\mathrm{CaV}$, and a factor to inject $\mathrm{Ca}^{2+}$. It has buttons for the application of blockers for the BK channel and the L-type $\mathrm{CaV}$ channel. Another on the left side, for the graphic recording of the simulations, where the oscilloscope screens are located for the display of the AP train (upper), the stimulus pulse (middle), and $\left[\mathrm{Ca}^{2+}\right]_{i}$ reached by the opening of the type- $\mathrm{L} \mathrm{CaV}$ channels (lower). The values of the parameters that appear in the interface when opening the simulator correspond to default values. The pulse of the current has a duration of $300 \mathrm{~ms}$ and an amplitude of $8 \mathrm{nA}$. $\left[\mathrm{Ca}^{2+}\right]_{\mathrm{e}}=3 \mathrm{mM},\left[\mathrm{Ca}^{2+}\right]_{\mathrm{i}}=0.05 \mu \mathrm{M}$. The conductances for $\mathrm{BK}$ and L-type $\mathrm{CaV}$ are at zero. These conditions correspond to a control simulation: the neuron does not have $\mathrm{BK}$ or $\mathrm{CaV}$ channels. The AP train that is recorded corresponds to the electrical activity of a neuron with voltage-gated $\mathrm{Na}^{+}$and $\mathrm{K}^{+}$channels. $\mathrm{BK}$ channels have been reported to have their effect on a part of the posthiperpolarization of AP in the soma, but not on the apical dendrites in hippocampal pyramidal neurons. The authors indicate that this difference is determined by a non-uniform distribution of ion channels, suggesting a greater distribution of BK in the 
soma (Poolos \& Johnston, 1999). L-type CaV channels are located mainly in the cell body and proximal dendrites (Hell et al., 1993). In this simulator, the L-type CaV/BK complex is located in the soma.

Figure 1. CaV-L/BK simulator user interface. Electrophysiological simulation with the current clamp technique of a Hodgkin and Huxley type neuron in the absence of the type-L CaV /BK complex. The upper oscilloscope display shows the AP train under these conditions (control). The lower oscilloscope display shows the internal $\mathrm{Ca}^{2+}$ concentration $(50 \mathrm{nM})$. The external and internal $\mathrm{Ca}^{2+}$ concentrations and current stimulus parameters have default values.

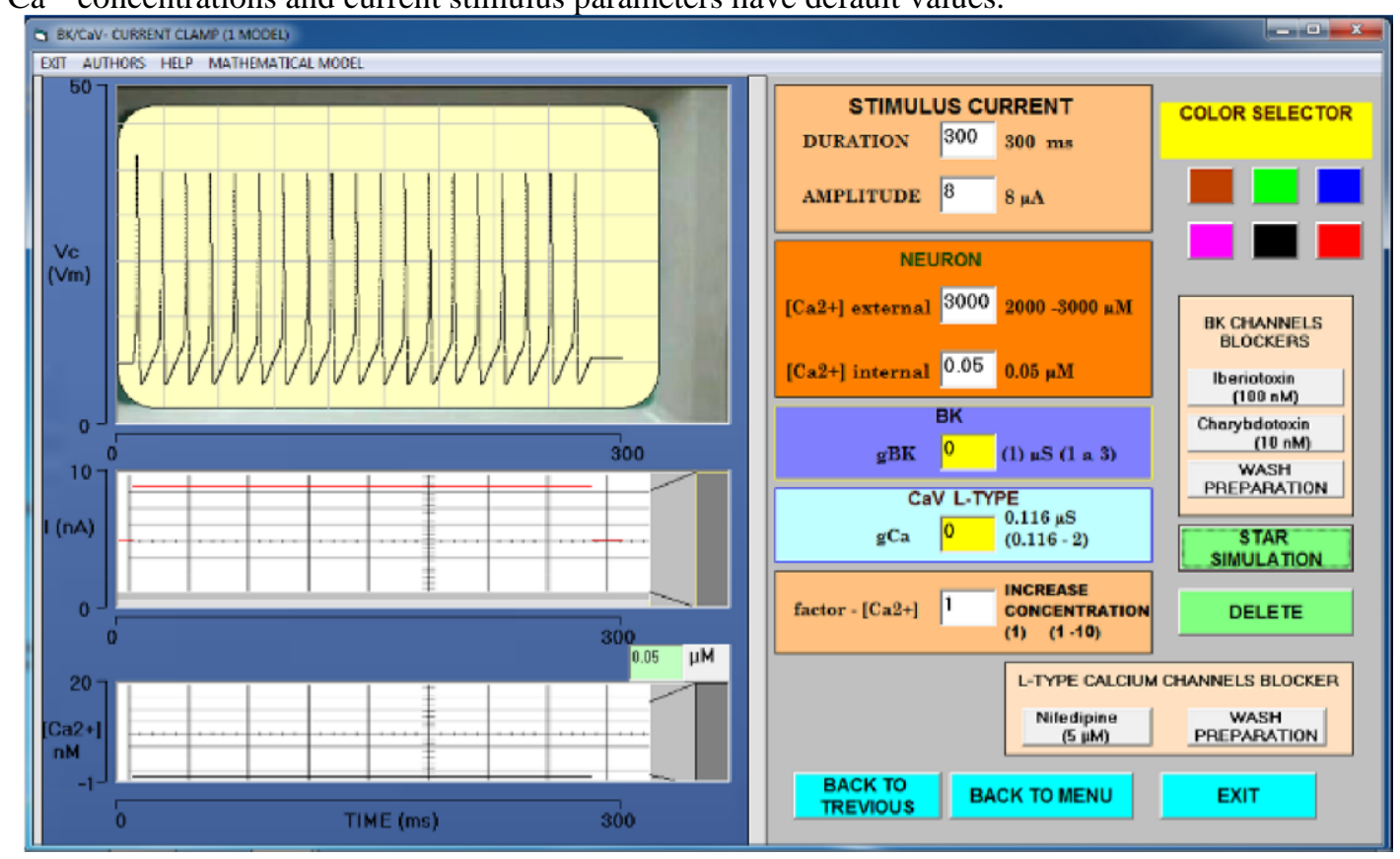

\subsection{SIMULATION OF SENSITIVITY TO VOLTAGE AND INTERNAL CALCIUM} CONCENTRATION.

BK channels are activated by voltage, by an increase in $\left[\mathrm{Ca}^{2+}\right]_{i}$ or by both (Cui et al., 2009). Both stimuli converge allosterically in the activation of BK channels by increasing concentrations of $\left[\mathrm{Ca}^{2+}\right]_{\mathrm{i}}$ that shift the conductance and voltage curve (G-V) to the left (Cui et al., 1997). In this work, the contribution of the voltage in the opening of the BK channel was tested through the effect it has on the AP train. Figure 2 , shows the electrophysiological simulation of a neuron stimulated with a pulse current with a duration of $300 \mathrm{~ms}$ and a current intensity of $8 \mathrm{nA}$. The external and internal $\mathrm{Ca}^{2+}$ concentrations are the same as those described in the control $\left(\left[\mathrm{Ca}^{2+}\right]_{\mathrm{e}}=3 \mathrm{mM}\right.$ y $\left.\left[\mathrm{Ca}^{2+}\right]_{\mathrm{i}}=0.05 \mu \mathrm{M}\right)$. The neuron has voltage-gated $\mathrm{Na}^{+}$and $\mathrm{K}^{+}$ channels and $\mathrm{BK}$ channels in the cell membrane. $\mathrm{CaV}$ channels are absent $(\mathrm{gCa}=0 \mu \mathrm{S})$. Under these experimental conditions, BK channels only respond to variations in membrane potential. The AP train ends in a shorter time (Figure 2, black trace) compared to the control (simulation in Figure 1). It can be seen how the frequency of AP decreases. Internal $\mathrm{Ca}^{2+}$ concentrations $(\leq 100 \mathrm{nM})$ do not activate the channel. In the simulated case, $\left[\mathrm{Ca}^{2+}\right]_{\mathrm{i}}$ remains at $50 \mathrm{nM}$ throughout the whole simulation time. This result agrees 
with previous works, where it is shown that BK channels are primarily and independently commanded by voltage (Toro et al., 1998). BK channels are sensitive to the increase of internal calcium concentration in the micromolar order (Meera et al., 1996). In the soma, they regulate the firing in burst of PA. To explore the effect of the increase in internal $\mathrm{Ca}^{2+}$, a simulation in a neuron with $\mathrm{Na}^{+}, \mathrm{K}^{+}, \mathrm{BK}$, and $\mathrm{L}$-type $\mathrm{CaV}$ channels was carried out. Under these conditions, the voltage-gated calcium channel opens with the depolarization of the membrane. An influx of $\mathrm{Ca}^{2+}$ occurs and internal $\mathrm{Ca}^{2+}$ increases in the order of micromolar. The simulation shows a slow increase of internal $\mathrm{Ca}^{2+}$ with respect to time until reaching a concentration of $13.9 \mu \mathrm{M}$ (red curve, lower oscilloscope screen, Figure 2). This concentration of $\mathrm{Ca}^{2+}$ activates jointly with the voltage to the BK channels, an adaptation of the AP train occurs and a decrease in the neuronal excitability is observed (AP train, red line, Figure 2). These results are similar to those reported by Bock and Stuart (Bock \& Stuart, 2016). The unique and singular properties of BK channels suggest that to be active, they must colocalize with $\mathrm{Ca}^{2+}$ channels and possess specialized sites for $\mathrm{Ca}^{2+}$ binding (Stefani et al., 1997). The analysis with a wide range of $\left[\mathrm{Ca}^{2+}\right]_{i}$ reveals that the function of the BK channel is exquisitely modulated by $\mathrm{Ca}^{2+}$ (Meera et al., 1996).

Figure 2. Voltage and calcium sensitivity of BK channels. The upper oscilloscope screen shows the AP train simulations: a neuron with only voltage-activated BK (black trace) and a neuron with voltage-activated BK and internal $\mathrm{Ca}^{2+}(\mathrm{red}$ trace). It is observed that the AP train ends in less time when the BK channel is activated with voltage and $\mathrm{Ca}^{2+}$ (it increases slowly until it reaches $13.9 \mu \mathrm{M}$, red trace with the red arrow in lower oscilloscope).

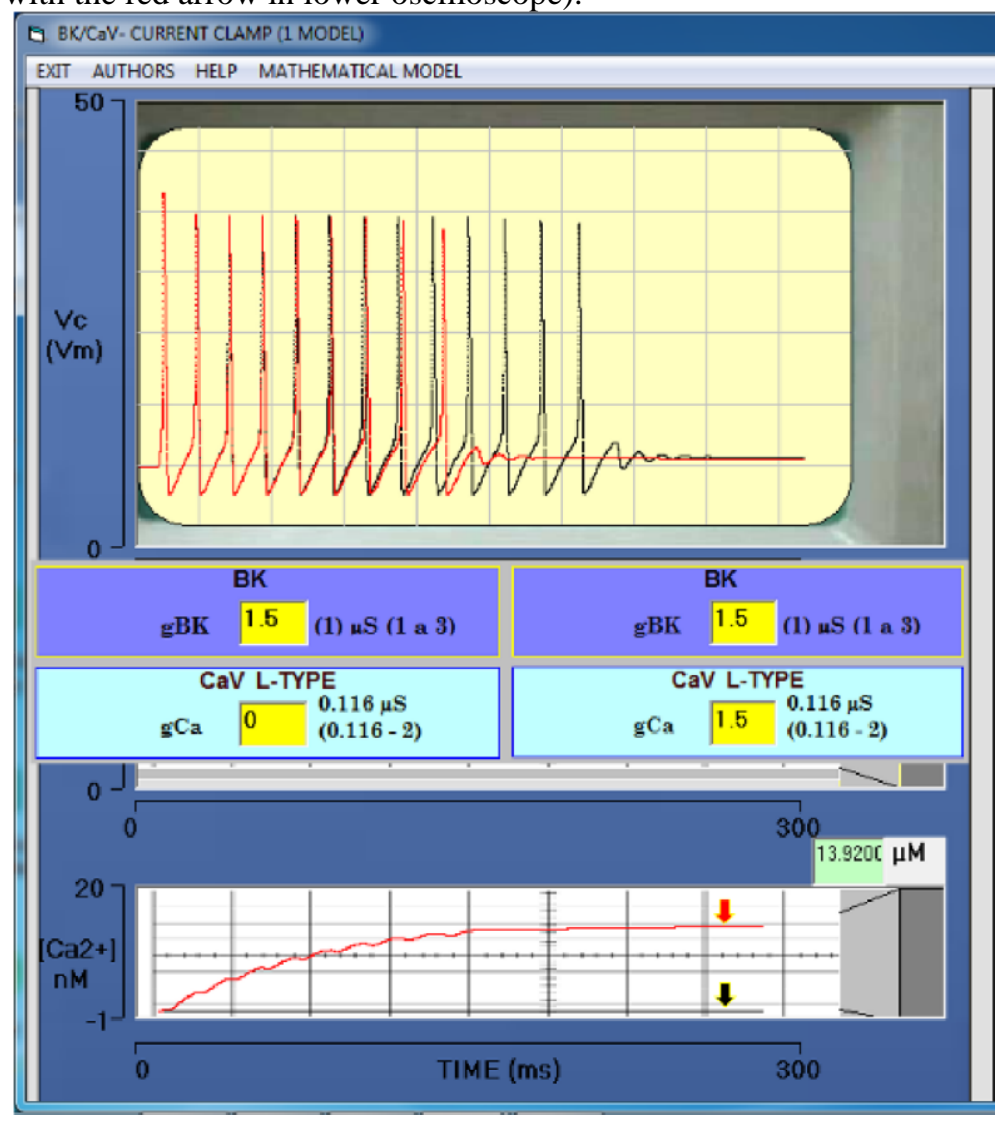




\subsection{ACTION POTENTIAL ADAPTATION BY BK SIMULATION.}

Figure 3, shows two simulations to compare the AP train of a control neuron (black line) against an experimental neuron with the type-L $\mathrm{CaV} / \mathrm{BK}$ complex, with the following values for the variables: $0.116(\mu \mathrm{S})$ for $\mathrm{g}_{\mathrm{Ca}}$ and $1(\mu \mathrm{S})$ for $\mathrm{g}_{\mathrm{BK}}$ and a calcium concentration of $1.2 \mu \mathrm{M}$ was reached (red trace). A decrease in firing frequency is observed. The frequency-time relationship of these two neurons and one more neuron with a type-L CaV/BK complex was determined, increasing $\mathrm{g}_{\mathrm{Ca}}(\mathrm{gCa}=0.5 \mu \mathrm{S}), \mathrm{gBK}=1 \mu \mathrm{S}$ (an internal calcium concentration of $4.87 \mu \mathrm{M}$ was reached) (Figure 4). A decrease is clearly observed in the firing frequency of the neurons that have $\mathrm{CaV}$ type-L/BK compared to the control neuron. The adaptation percentage for the control neuron $\mathrm{F}_{\mathrm{adap}}=0 \%$, for the neuron with $\mathrm{g}_{\mathrm{Ca}}=0.0116 \mu \mathrm{S}, \mathrm{F}_{\mathrm{adap}}=$ $12.7 \%$; for the neuron with $g_{\mathrm{Ca}}=0.5 \mu \mathrm{S}, \mathrm{F}_{\mathrm{adap}}=19 \%$. $\left(\mathrm{F}_{\mathrm{adap}}=\left(\mathrm{f}_{0}-\mathrm{f}_{\mathrm{ss}}\right) / \mathrm{f}_{0}\right.$, where $\mathrm{f}_{0}$ is the initial frequency and $\mathrm{f}_{\mathrm{ss}}$ is the frequency in the steady state). A greater adaptation occurs with a greater $\left[\mathrm{Ca}^{2+}\right]_{i}$ generated by a greater conductance of the type- $\mathrm{L} \mathrm{CaV}$ channel. An adaptation process was studied in a theoretical model for cortical pyramidal cells (Wang, 1998). In this model, the adaptation percentage was much higher $F_{\text {adap }}$ $=57 \%$. In this case, the model is integrated by two compartments with an electrotonic junction and $\mathrm{g}_{\mathrm{Na}}=$ $145 \mathrm{mS} / \mathrm{cm}^{2}$. In our case, $\mathrm{g}_{\mathrm{Na}}=120 \mathrm{mS} / \mathrm{cm}^{2}$. At a higher $\mathrm{Na}^{+}$conductance, the AP train presents a greater frequency and the adaptation percentage is greater. Theoretical and experimental results (Marcantoni et al., 2010) indicate that the action of the BK channel is to reduce the AP frequency and to decrease the excitability. The $\mathrm{Ca}^{2+}$ requirements of order $\mu \mathrm{M}$ for the $\mathrm{BK}$ channel to regulate the excitability, suggest a colocalization of the $\mathrm{CaV}$ - BK channels (Toro et al., 1998). 
Figure 3. Simulation of AP train in neuron with BK and CaV-L. The black line corresponds to an AP train from a control neuron. The trace in red corresponds to the AP train in a neuron with $\mathrm{g}_{\mathrm{BK}}=1 \mu \mathrm{S}, \mathrm{g}_{\mathrm{c}}=0.116 \mu \mathrm{S},[\mathrm{Ca} 2+]_{\mathrm{i}}=1.2 \mu \mathrm{M}$, it is observed how the APs decrease their frequency and produce an adaptation.

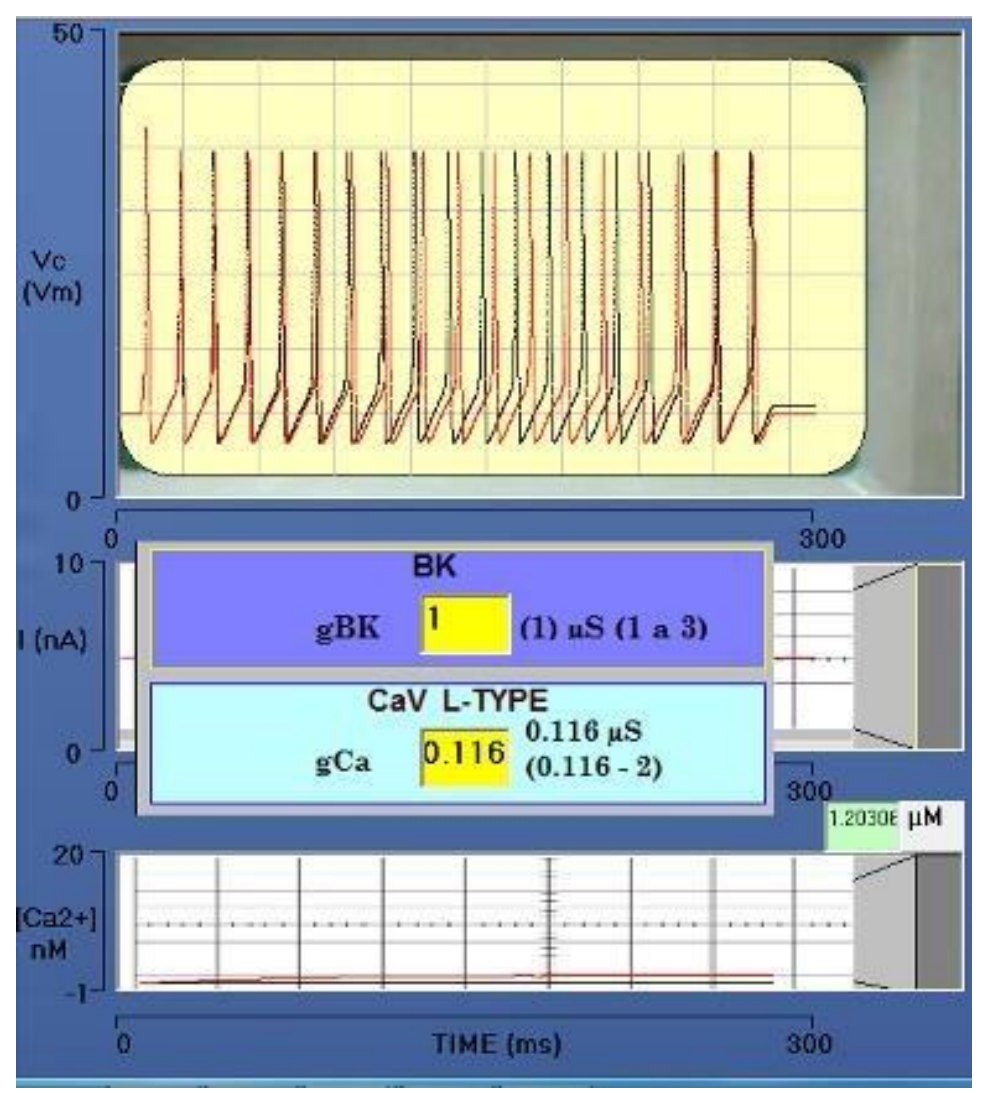

Figure 4. Frequency-time relationship. In the control neuron, it is observed how the AP frequency remains constant throughout the time of the simulation (black squares). The activation of the BK channels by the type-L CaV action $\left(\mathrm{g}_{\mathrm{BK}}=1 \mu \mathrm{S}, \mathrm{g}_{\mathrm{Ca}}=0.116\right.$ $\mu \mathrm{S}$ ) decreases the AP frequency throughout the stimulus time (circles in red). A greater activity of the CaV channels activate more the $\mathrm{BK}$ channels $\left(\mathrm{g}_{\mathrm{BK}}=1 \mu \mathrm{S}, \mathrm{g}_{\mathrm{Ca}}=0.5 \mu \mathrm{S}\right)$ producing a greater adaptation (green triangles).

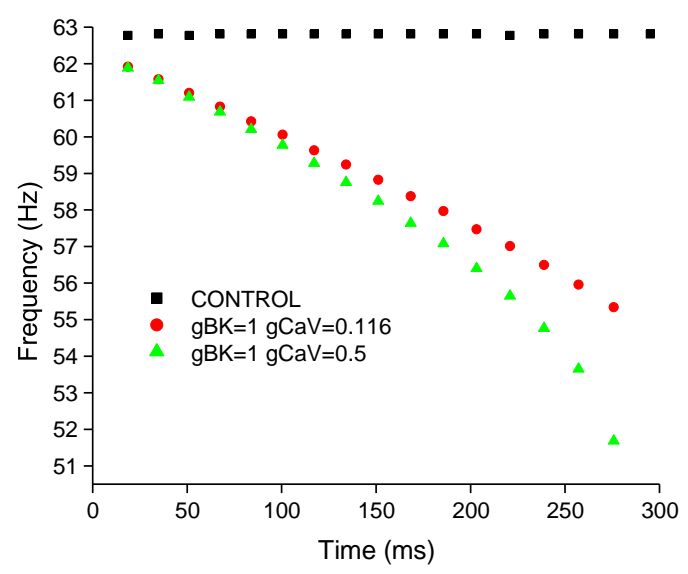




\subsection{VOLTAGE CLAMP EXPERIMENTS OF THE L-TYPE CAV / BK COMPLEX}

The I-V relationship for $\mathrm{BK}$ and $\mathrm{CaV}$ was explored and the $\mathrm{Ca}^{2+}$ concentration generated by the $\mathrm{Ca}^{2+}$ current was calculated (Wang, 1998). A simulator that allows carrying experiments under voltage clamp conditions was developed. The user interface has a data input module: stimulus duration and voltage, initial conditions: $\left[\mathrm{Ca}^{2+}\right]_{\mathrm{e}}=2 \mathrm{mM},\left[\mathrm{Ca}^{2+}\right]_{\mathrm{i}}=50 \mathrm{nM}$, with $\mathrm{g}_{\mathrm{BK}}$ and type- $\mathrm{L} \mathrm{gCaV}=1$ and $0.116 \mu \mathrm{S}$, respectively. It has five oscilloscope screens that display: the BK current ( $\left.\mathrm{I}_{\mathrm{BK}}\right)$, the L-type CaV current $\left(\mathrm{I}_{\mathrm{CaV}}\right),\left[\mathrm{Ca}^{2+}\right]_{\mathrm{i}}$, and the current-voltage relationship (I-V) for $\mathrm{I}_{\mathrm{BK}}$ and $\mathrm{I}_{\mathrm{CaV}}$ (Figure 5). $\mathrm{I}_{\mathrm{BK}}$ and $\mathrm{I}_{\mathrm{CaV}}$ currents were evoked with voltage pulses in the range of -50 to $40 \mathrm{mV}$ with steps of $10 \mathrm{mV}, \mathrm{V}_{\mathrm{H}}=-93 \mathrm{mV}$. The macroscopic $\mathrm{I}_{\mathrm{BK}}$ current is displayed on the upper oscilloscope screen. An outgoing current that inactivates very slowly with time is observed (Helton et al., 2005). The macroscopic $\mathrm{I}_{\mathrm{CaV}}$ current is displayed on the lower oscilloscope screen. An incoming stream that does not inactivate is observed. Changes in $\left[\mathrm{Ca}^{2+}\right]_{\mathrm{i}}$ are displayed on the intermediate oscilloscope screen. The current-voltage (I-V) curves for $\mathrm{I}_{\mathrm{BK}}$ and $\mathrm{I}_{\mathrm{CaV}}$ are displayed in the central part of the user interface. The $\mathrm{I}_{\mathrm{BK}}$ follows the kinetics (mirrored) of $\mathrm{I}_{\mathrm{CaV}}$. The Ltype $\mathrm{CaV}$ channel commands the BK channel (Figure 5).

Figure 5. User interface of the simulator for voltage clamp experiments. Simulation with $(\mu \mathrm{S}): \mathrm{g}_{\mathrm{BK}}=1, \mathrm{~g}_{\mathrm{Ca}}=0.116$. It was stimulated with voltage pulses ranging from -50 to $40 \mathrm{mV}$ with steps of $10 \mathrm{mV}$. The upper oscilloscope display shows the macroscopic BK current, the middle oscilloscope display shows the internal $\mathrm{Ca}^{2+}$ concentration, and the lower oscilloscope shows the macroscopic $\mathrm{Ca}_{2}+$ current. The $\left[\mathrm{Ca}^{2+}\right]_{\mathrm{i}}$ increase from 0.05 to $1.87 \mu \mathrm{M}$. The I-V curves show how IBK follows ICaV kinetics.

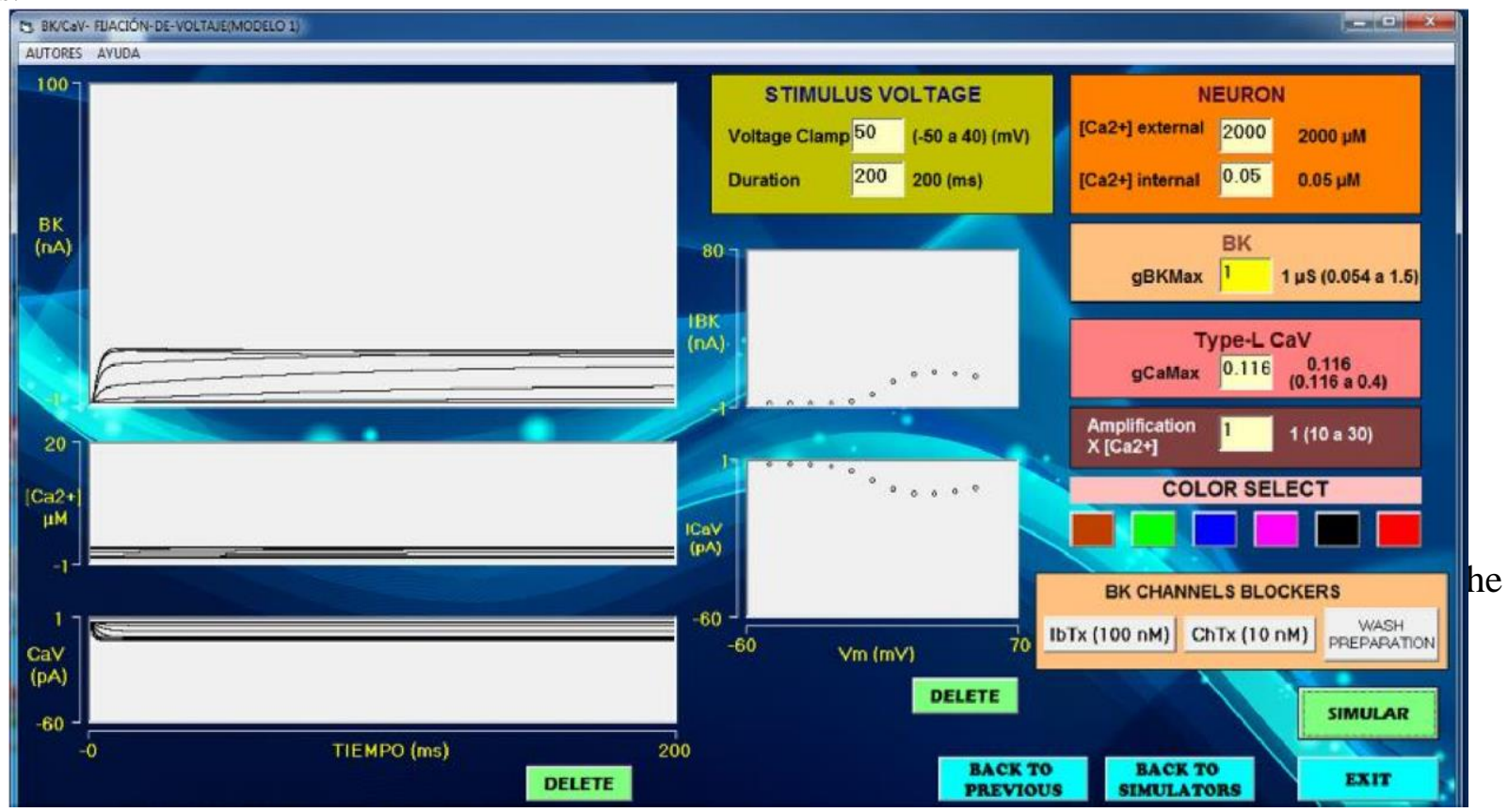


The analysis of the conductance-voltage (G-V) normalized for $\mathrm{BK}$ and type- $\mathrm{L} \mathrm{CaV}$ with the Boltzmann equation. Under the simulation conditions for $\mathrm{G}-\mathrm{V}$ of the $\mathrm{I}_{\mathrm{CaV}}, \mathrm{V}_{1 / 2}=-2.79(\mathrm{mV})$ and for $\mathrm{I}_{\mathrm{BK}}$, $\mathrm{V}_{1 / 2}=5.06(\mathrm{mV})$. First the $\mathrm{CaV}$ channel opens, $\mathrm{Ca}^{2+}$ enters the neuron, and the $\mathrm{BK}$ channel is activated. The G-V curve for BK follows the kinetics of the G-V curve for L-type CaV (Figure 6).

Figure 6. G-V relationship for BK and L-type CaV channels. Comparison of the G-V curves of the L-type CaV channel (red circles) and the BK channel (black squares). Experiments were performed in voltage clamp with pulses from -50 to $40 \mathrm{mV}$ with steps of $10 \mathrm{mV}$. The solid lines are the fit to the Boltzmann equation at $23{ }^{\circ} \mathrm{C}$.

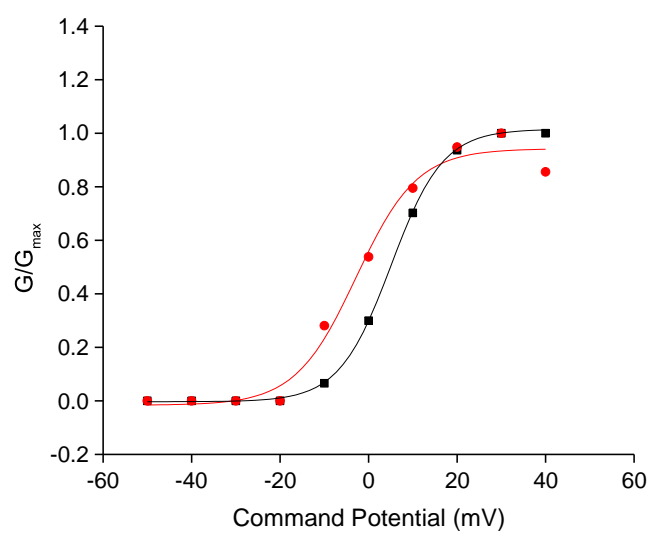

\section{CONCLUSIONS}

The properties of L-type $\mathrm{Ca}^{2+}$ channels can have important regulatory effects on the properties of action potentials. The membrane potential that regulates $\mathrm{CaV}$ channels may dynamically regulate the degree of activation of the BK current and produce profound effects on cell excitability. Selective coupling between L-type $\mathrm{CaV}$ and $\mathrm{BK}$ channels in the soma may provide a key mechanism that enables specific modulation of $\mathrm{Ca}^{2+}$ channels to exert profound physiological and pathological consequences. The decrease in cellular excitability could contain the appearance of repetitive APs that lead to disorders such as epilepsy. Under conditions where the electrophysiology of BK channels is normal, an increase in $\mathrm{g}_{\mathrm{Na}}$ intensifies excitability again. The mechanisms that regulate cell excitability are complex and the precise role of ionic currents and their synchronization still requires intensive study. The BK channels are $\left[\mathrm{Ca}^{2+}\right]_{\mathrm{i}}$ sensors, a sudden increase in $\mathrm{Ca}^{2+}$ is the signal for their activation and to stop the AP train. 


\section{REFERENCES}

Augustine, G. J., Santamaria, F., Tanaka, K., \& Carolina, N. (2003). Local Calcium Signaling in Neurons Review. Neuron, 40, 331-346. https://doi.org/10.1016/s0896-6273(03)00639-1

Bean, B. P. (1989). Classes of calcium channels in vertebrate cells. Annu Rev Fisiol, 51:367-384. https://doi.org/10.1146/annurev.ph.51.030189.002055

Bellono, N. W., Leitch, D. B., Julius, D., \& Francisco, S. (2017). Molecular basis of ancestral vertebrate electroreception. Nature, 543(Xxxx), 391-396. https://doi.org/10.1038/nature21401.Molecular

Bock, T., \& Stuart, G. J. (2016). The impact of BK channels on cellular excitability depends on their subcellular location. Front Cell Neurosci, 10(AUG), 1-8. https://doi.org/10.3389/fncel.2016.00206

Butler, A., Tsunoda, S., McCobb, D. P., Wei, A., Salkoff, L., Gautam, N., Gilman, G., \& Chem, J. B. (1993). mSlo, a complex mouse gene encoding "Maxi" calcium-activated potassium channels. Science, 261, 221-224. https://doi.org/10.1126/science.7687074

Contet, C., Goulding, S. P., Kuljis, D. A., \& Barth, A. L. (2016). BK channel sin the CNS. Int Rev Neurobiol, 128, 281-342. https://doi.org/10.1016/bs.irn.2016.04.001.BK

Contreras, G. F., Castillo, K., Enrique, N., Carrasquel-Ursulaez, W., Castillo, J. P., Milesi, V., Neely, A., Alvarez, O., Ferreira, G., Gonzalez, C., \& Latorre, R. (2013). A BK (Slo1) channel journey from molecule to physiology. Channels, 7(6), 442-458. https://doi.org/10.4161/chan.26242

Cox, D. H. (2014). Modeling a $\mathrm{Ca}^{2+}$ channel/BKCa channel complex at the single-complex level. Biophys $J$, 107(12), 2797-2814. https://doi.org/10.1016/j.bpj.2014.10.069

Cui, J., Cox, D. H., \& Aldrich, R. W. (1997). Intrinsic voltage dependence and $\mathrm{Ca}^{2+}$ regulation of mslo large conductance Ca-activated $\mathrm{K}^{+}$channels. J Gen Physiol, 109(May), 647-673. https://doi.org/10.1085/jgp.109.5.647

Cui, J., Yang, H., \& Lee, U. S. (2009). Review Molecular mechanisms of BK channel activation. CMLS, 66, 852- 875. https://doi.org/10.1007/s00018-008-8609-x

Galvez, A., Gimenez-Gallego, G., Reuben, J. P., Roy-Contancin, L., Feigenbaum, P., Kaczorowski, G. J., \& Garcia, M. L. (1990). Purification and characterization of a unique, potent, peptidyl probe for the high conductance calcium-activated potassium channel from venom of the scorpion Buthus tamulus. $J$ Biol Chem, 265(19), 11083-11090. https://doi.org/10.13039/501100006393

Ha, G. E., \& Cheong, E. (2017). Spike frequency adaptation in neurons of the central nervous system. Exp Neurobiol, 26(4), 179-185. https://doi.org/10.5607/en.2017.26.4.179

Hell, J. W., Westenbroek, R. E., Warner, C., Ahlijanian, M. K., Prystay, W., Gilbert, M. M., Snutch, T. P., \& Catterall, W. A. (1993). Identification and differential subcellular localization of the neuronal class C and class D L-type calcium channel $\alpha 1$ subunits. J Cell Biol, 123(4), 949-962.

https://doi.org/10.1083/jcb.123.4.949 
Helton, T. D., Xu, W., \& Lipscombe, D. (2005). Neuronal L-type calcium channels open quickly and are inhibited slowly. J Neurosci, 25(44), 10247-10251. https://doi.org/10.1523/JNEUROSCI.108905.2005

Hodgkin, A. L., \& Huxley, A. F. (1952). A quantitative description of membrane current and its application to conduction and excitation in Nerve. J Physiol, 117(4), 500-544.

https://doi.org/10.1113/jphysiol.1952.sp004764

Indriati, D. W., Kamasawa, N., Matsui, K., Meredith, A. L., Watanabe, M., \& Shigemoto, R. (2013). Quantitative localization of Cav2.1 (P/Q-Type) voltage-dependent calcium channels in Purkinje cells: Somatodendritic gradient and distinct somatic Coclustering with calcium-activated potassium channels. $J$ Neurosci, 33(8), 3668-3678. https://doi.org/10.1523/JNEUROSCI.2921-12.2013

Jackson, W. F. (2018). Potassium channels in regulation of vascular smooth muscle contraction and growth. Adv Pharmacol, 78, 78-89. https://doi.org/10.1016/bs.apha.2016.07.001.Potassium

Kaufmann, W. A., Ferraguti, F., Fukazawa, Y., Kasugai, Y., Shigemoto, R., Laake, P., Sexton, J. A., Ruth, P., Wietzorrek, G., Knaus, H. G., Storm, J. F., \& Ottersen, O. P. (2009). Large-conductance calciumactivated potassium channels in Purkinje cell plasma membranes are clustered at sites of hypolemmal microdomains. J Comp Neurol, 515(2), 215-230.

https://doi.org/10.1002/cne.22066

Kshatri, A. S., Gonzalez-Hernandez, A., \& Giraldez, T. (2018). Physiological Roles and Therapeutic Potential of $\mathrm{Ca}^{2+}$ Activated Potassium Channels in the Nervous System. Front Mol Neurosci, 11(July), 118. https://doi.org/10.3389/fnmol.2018.00258

Lancaster, B., \& Nicoll, R. A. (1987). Properties of two calcium-activated hyperpolarizations in rat hippocampal neurones. J Physiol, 389(1), 187-203.

https://doi.org/10.1113/jphysiol.1987.sp016653

Latorre, Ramon, Castillo, K., Carrasquel-Ursulaez, W., Sepulveda, R. V., Gonzalez-Nilo, F., Gonzalez, C., \& Alvarez, O. (2017). Molecular determinants of BK channel functional diversity and functioning. Physiol Rev, 97(1), 39-87. https://doi.org/10.1152/physrev.00001.2016

Lee, U. S., \& Cui, J. (2010). BK channel activation : structural and functional insights. Trends Neurosci, 33(9), 415-423. https://doi.org/10.1016/j.tins.2010.06.004

Li, Q., \& Yan, J. (2016). Modulation of channels function by auxiliary beta and gamma subunits. Int Rev Neurobiol, 128, 51-90. https://doi.org/10.1016/bs.irn.2016.03.015

Marcantoni, A., Vandael, D. H. F., Mahapatra, S., Carabelli, V., Sinnegger-brauns, M. J., Striessnig, J., \& Carbone, E. (2010). Loss of Cav1.3 Channels Reveals the Critical Role of L-Type and BK Channel Coupling in Pacemaking Mouse Adrenal Chromaffin Cells. J Neurosci, 30(2), 491-504. https://doi.org/10.1523/JNEUROSCI.4961-09.2010

Meera, P., Wallner, M., Jiang, Z., \& Toro, L. (1996). A calcium switch for the functional coupling between $\alpha($ hslo $)$ and $\beta$ subunits (KV,Ca $\beta$ ) of maxi K channels. FEBS Letters, 382(1-2), 84-88.

https://doi.org/10.1016/0014-5793(96)00151-2 
Miranda, P., Holmgren, M., \& Giraldez, T. (2018). Voltage-dependent dynamics of the BK channel cytosolic gating ring are coupled to the membrane-embedded voltage sensor. ELife, 7, 1-18.

https://doi.org/10.7554/eLife.40664

Misonou, H., Menegola, M., Buchwalder, L., Park, E., Meredith, A., Rhodes, K., Aldrich, R., \& Trimmer, J. (2006). Immunolocalization of the $\mathrm{Ca}^{2+}$-activated $\mathrm{K}^{+}$channel Slo1 in axon and nerve terminals of mammalian brain and cultured neurons. J Comp Neurol, 496(3), 289-302. https://doi.org/10.1002/cne.20931

Müller, A., Kukley, M., Uebachs, M., Beck, H., \& Dietrich, D. (2007). Nanodomains of single $\mathrm{Ca}^{2+}$ channels contribute to action potential repolarization in cortical neurons. J Neurosci, 27(3), 483-495. https://doi.org/10.1523/JNEUROSCI.3816-06.2007

Poolos, N. P., \& Johnston, D. (1999). Calcium-activated potassium conductances contribute to action potential repolarization at the soma but not the dendrites of hippocampal CA1 pyramidal neurons. $J$ Neurosci, 19(13), 5205-5212. https://doi.org/10.1523/jneurosci.19-13-05205.1999

Pospischil, M., Toledo-Rodriguez, M., Monier, C., Piwkowska, Z., Bal, T., Frégnac, Y., Markram, H., \& Destexhe, A. (2008). Minimal Hodgkin-Huxley type models for different classes of cortical and thalamic neurons. Biol Cybern, 99(4-5), 427-441. https://doi.org/10.1007/s00422-008-0263-8

Stefani, E., Ottolia, M., Noceti, F., Olcese, R., Wallner, M., Latorre, R., \& Toro, L. (1997). Voltagecontrolled gating in a large conductance $\mathrm{Ca}^{2+}$-sensitive $\mathrm{K}^{+}$channel (hslo). Proc Natl Acad Sci USA, 94(10), 5427-5431. https://doi.org/10.1073/pnas.94.10.5427

Sterratt, D., Graham, B., Gillies, A., \& Willshaw, D. (2011). Principles of Computational Modelling in Neuroscience. Cambridge: Cambridge University Press.

Striessnig, J., Koschak, A., Sinnegger-Brauns, M. J., Hetzenauer, A., Nguyen, N. K., Busquet, P., Pelster, G., \& Singewald, N. (2006). Role of voltage-gated L-type $\mathrm{Ca}^{2+}$ channel isoforms for brain function. Biochem Soc Trans, 34(5), 903-909. https://doi.org/10.1042/BST0340903

Toro, L., Wallner, M., Meera, P., Tanaka, Y., \& Ca, C. K. (1998). Maxi-K(Ca), a unique member of the voltage-gated K channel superfamily. New Physiol Sci, 13, 112-117. https://doi.org/

10.1152/physiologyonline.1998.13.3.112

Traub, R. D. (1982). Simulation of intrinsic bursting in CA3 hippocampal neurons. Neuroscience, 7(5), 1233-1242. https://doi.org/10.1016/0306-4522(82)91130-7

Traub, R. D., Wong, R. K. S., Miles, R., \& Michelson, H. (1991). A model of a CA3 hippocampal pyramidal neuron incorporating voltage-clamp data on intrinsic conductances. J Neurophysiol, 66(2), 635650. https://doi.org/10.1152/jn.1991.66.2.635

Tsien, R W, Lipscombe, D., \& Madison, D. V. (1988). Multiple types of neuronal caldum channels and their selective modulation. Trends Neurosci, 11(10): 431-438. https://doi.org/10.1016/01662236(88)90194-4 
Tsien, Richard W., Ellinor, P. T., \& Horne, W. A. (1991). Molecular diversity of voltage-dependent $\mathrm{Ca}^{2+}$ channels. Trends Pharmacol Sci, 12, 349-354. https://doi.org/10.1016/01656147(91)90595-J

Vivas, O., Moreno, C. M., Santana, L. F., Hille, B., \& States, U. (2017). Proximal clustering between BK and $\mathrm{CaV} 1.3$ channels promotes functional coupling and $\mathrm{BK}$ channel activation at low voltage. eLife, 6:e28029. https://doi.org/10.7554/eLife.28029

Wang, X. J. (1998). Calcium coding and adaptive temporal computation in cortical pyramidal neurons. $J$ Neurophysiol, 79(3), 1549-1566. https://doi.org/10.1152/jn.1998.79.3.1549

Whitt, J. P., Mcnally, B. A., \& Meredith, A. L. (2018). Differential contribution of Ca2+ sources to day and night BK current activation in the circadian clock. J Gen Physiol, 150(2), 259-275. https://doi.org/ 10.1085/jgp.201711945

Zill, D. G. (1988). Ecuaciones diferenciales con aplicaciones. México: Grupo Editorial Iberoamérica. 